\title{
COUMARINS OF THE ROOTS OF ANGELICA SAXATILIS
}

L. G. Avramenko, G. K. Nikonov, and M. G. Pimenov

Khimiya Prirodnykh Soedinenii, Vol. 5, No. 5, p. 436, 1969

In the roots and stem roots of Angelica saxatilis Turcz. collected in the Khabarovsk territory in the surroundings of a mixture of the village of Ayan there is 1.09\% of lactones altogether, consisting of a mixture of six compounds with $R_{f} 0.92$, $0.89,0.82,0.59,0.15$, and 0.03 [hexane-benzene-methanol $(5: 4: 1)$ system; Leningrad type "B" paper previously impregnated with a $10 \%$ solution of formamide in methanol].

By the chromatographic separation of a methanolic extract of the roots on a column of acidic alumina we have isolated the lactones $\mathrm{C}_{16} \mathrm{H}_{14} \mathrm{O}_{4}, \mathrm{mp} 108-109^{\circ} \mathrm{C}, \mathrm{R}_{f} 0.92$, yield $0.1 \%$ (A); $\mathrm{C}_{16} \mathrm{H}_{14} \mathrm{O}_{4}, \mathrm{mp} 101-102^{\circ} \mathrm{C}, \mathrm{R}_{f} 0.89$, yield $0.23 \%(\mathrm{~B}) ; \mathrm{C}_{12} \mathrm{H}_{8} \mathrm{O}_{4}, \mathrm{mp} 188-190^{\circ} \mathrm{C}, \mathrm{R}_{f} 0.82$, yield $0.017 \%$ (C); $\mathrm{C}_{11} \mathrm{H}_{6} \mathrm{O}_{4}, \mathrm{mp} 245-247^{\circ} \mathrm{C}, \mathrm{R}_{f} 0.1$ (D); and $\mathrm{C}_{16} \mathrm{H}_{16} \mathrm{O}_{6}$, $\mathrm{mp} 129-130^{\circ} \mathrm{C},[\alpha]_{\mathrm{D}}^{21}+24^{\circ}$ (c 0.94 ; acetone), $\mathrm{R}_{f} 0.03$, yield $0.08 \%$ (E).

On the basis of their physicochemical constants, IR spectra, and the absence of a depression of the melting point in mixtures with authentic samples, the lactones $A, B, C, D$, and $E$ have been identified as isoimperatorin, imperatorin, bergapten, xanthotoxol, and ( + )-oxypeucedanin hydrate, respectively.

Paper chromatography shows that xanthotoxol is not present in the plant and is probably formed as the result of the decomposition of the imperatorin on the alumina.

In addition to the coumarins mentioned, $\beta$-sitosterol, $\mathrm{C}_{29} \mathrm{H}_{50} \mathrm{O}, \mathrm{mp} 138-140^{\circ} \mathrm{C}$, yield $0.05 \%$, identified by its IR spectrum and a mixed melting point, was isolated as an accompanying substance.

(+)-Oxypeucedanin hydrate has been isolated previously from the closely related species A. gmelinii (DC.) M. Pimen. [1], and isoimperatorin and imperatorin from species of the Angelica section A. sylvestris L. [2] and A. genuflexa Nut. [3]. Thus a study of the chemical composition of the roots confirms the chemosystematic characteristics found previously in an investigation of the coumarins of the fruit of A. saxatilis [4], a species occupying an intermediate position between the sections Coelopleurum and Angelica.

\section{REFERENCES}

1. G. K. Nikonov, R. K. Vermei, and M. G. Pimenov, ZhOKh, 34, 4, 1353, 1964.

2. G. Caporale and G. Rodighiero, Ricerta sci., 2, 124, 1961.

3. G. K. Nikonov, N. I. Rodina, and M. G. Pimenov, Aptechn. delo, 2, 23, 1964.

4. G. K. Nikonov, M. G. Pimenov, and E. B. Zorin, Rast. res. , 4, 505, 1966.

23 May 1.969

All-Union Scientific-Research Institute for Medicinal Plants

UDC $547-314$

\section{HERNIARIN FROM ARTEMISIA DIFEUSA}

V. A. Tarasov, Sh. Z. Kasymov, and G. P. Sidyakin

Khimiya Prirodnykh Soedinenii, Vol. 5, No. 5, pp. 436-437, 1969

It is known [1] that the flower heads of Artemisia diffusa contain a large amount (3.8\%) of santonin. We have studied this species of wormwood, collected in the northern part of the Golodnaya steppe (UzSSR), in the early vegetation periods. We found no $\alpha$ - or $\beta$-santonin or other $\gamma$-lactones either in the epigeal part of the early crop (April) or in the flower heads in the beginning of September.

From the epigeal part of this wormwood collected in May, extraction with hot water and subsequent chromatography of the nelltral fraction of the extract on a column of alumina yielded a crystalline substance $\mathrm{C}_{10} \mathrm{H}_{8} \mathrm{O}_{3}$ with $\mathrm{mp} 117^{\circ} \mathrm{C}$ (from ether) with the characteristic properties of coumarin compounds-it fluoresced lilac in UV radiation and was shown up by diazotized sulfanilic acid. IR spectrum, $\mathrm{cm}^{-1}: 1715$ ( $\mathrm{C}=\mathrm{O}$ of a coumarin), 1610, 1505 (aromatic double bonds). 